\title{
Agronomic performance of new strawberry cultivars in southern Brazil
}

\author{
Desempenho agronômico de novos cultivares de morango no sul do Brasil
}

\author{
Marllon Fernando Soares dos Santos*, Antonio Felippe Fagherazzi, Juliana Martins de Lima, Bruna \\ Miranda Costa, Francine Regianini Nerbass, Aike Anneliese Kretzschmar, Leo Rufato
}

State University of Santa Catarina, Lages, SC, Brazil. * Author for correspondence: marllon.soares@outlook.com

Submission: 07/01/2021 | Acceptance: 26/03/2021

\begin{abstract}
The choice of cultivars to be used by strawberry farmers is essential since it could determine the success of the crop. The present study aimed to evaluate the productive and qualitative performance of strawberry genotypes grown in Vacaria, RS, Brazil. Twelve strawberry genotypes were compared, constituting the different treatments: cultivars Strawberry Festival, Oso Grande, Jonica, and Pircinque, and selections FRF PA3, FRF CE 51, FRF CE 56, FRF PIR 29, FRF PIR 54, FRF 85.04, FRF 149.18, and FRF 102.21. The seedlings were transplanted on May 13,2014, in a semi-hydroponic cultivation system, adopting a randomized block design with four blocks and an experimental unit of ten useful plants. The variables evaluated were the number of fruits, total production per plant, productivity, commercial productivity, fresh fruit mass, commercial percentage, soluble solids, titratable acidity, soluble solids to total acidity ratio, pulp firmness, and production seasonality. The mean values were subjected to an analysis of variance and multivariate analysis, and their means were compared by the Scott-Knott test at a $5 \%$ error probability. Cultivar Strawberry Festival and selection FRF 102.21 showed higher productions (1138 g plant ${ }^{-1}$ nd 1019 g plant ${ }^{-1}$, respectively) and quantities of fruits produced (85 un plant ${ }^{-1}$ and 87 un plant $^{-1}$, respectively). Cultivar Jonica and selection FRF 85.4 showed higher percentages of marketable fruits. The Pircinque cultivar was prominent for sugar content, presenting a value $24 \%$ superior to the general average of the cultivars. Cultivars Strawberry Festival, Jonica, and Pircinque and selection FRF 102.21 showed the highest qualitative and quantitative gains for the region of Vacaria, RS, Brazil.
\end{abstract}

KEYWORDS: Fragaria $\mathrm{x}$ ananassa Duch; adaptability; productivity.

\section{RESUMO}

A escolha dos cultivares a serem utilizadas pelos produtores de morangos é fundamental, pois pode determinar o sucesso da cultura. O presente estudo tem como objetivo avaliar o desempenho produtivo e qualitativo de genótipos de morangueiro cultivados em Vacaria, RS, Brasil. Foram comparados 12 genótipos de morangueiro, constituindo os diferentes tratamentos: cultivares Strawberry Festival, Oso Grande, Jonica e Pircinque, e seleções FRF PA3, FRF CE 51, FRF CE 56, FRF PIR 29, FRF PIR 54, FRF 85,04, FRF 149,18, e FRF 102,21. As mudas foram transplantadas em 13 de maio de 2014, em sistema de cultivo semi-hidropônico, adotando-se o delineamento em blocos casualizados, com quatro blocos e unidade experimental de dez plantas úteis. As variáveis avaliadas foram número de frutos, produção total por planta, produtividade, produtividade comercial, massa fresca do fruto, porcentagem comercial, sólidos solúveis, acidez titulável, relação (sólidos solúveis/acidez total), firmeza da polpa e a sazonalidade da produção. Os valores médios foram submetidos à análise de variância e análise multivariada, e suas médias comparadas pelo teste de Scott-Knott a $5 \%$ de probabilidade de erro. $O$ cultivar Strawberry Festival e seleção FRF 102,21 apresentaram maior produção (1138 e $1019 \mathrm{~g}^{\text {planta-1 }}{ }^{-1}$ ) e quantidade de frutos produzidos (85 e 87 un planta $^{-1}$ ). A cultivar Jonica e a seleção FRF 85,4 apresentaram maior porcentagem de frutos comerciáveis. O cultivar Pircinque se destacou-se pelo seu teor de açúcares, apresentando um valor $24 \%$ superior à média geral dos cultivares. As cultivares Strawberry Festival, Jonica e Pircinque e seleção FRF 102,21 apresentaram os maiores ganhos qualitativos e quantitativos para a região de Vacaria, RS.

PALAVRAS-CHAVE: Fragaria $x$ ananassa Duch; adaptabilidade; produtividade. 


\section{INTRODUCTION}

The national fruit production generates a cultivated area of approximately 2.70 million hectares, a production of roughly 40 million tons, and around five million jobs, making Brazil the third largest fruit producer worldwide, standing out in Latin America as the second-largest producer of small fruits according to FAOSTAT (2019).

The fruit production chain is one of the agribusiness sectors that most generate jobs and income. According to the FAOSTAT (2019) strawberry is a main species was represented the small fruits in cultivation in Brazil, with approximately 4,500 hectares and an annual production around 165,440 tons.

Regarding total production, strawberry is the main fruit produced and consumed among the species that make up small fruits in Brazil (FAGHERAZZI et al. 2017a). The commercial interest in the fruit is due to the notable demand by the consumer market and the possibility of diversification since the product may be used both for fresh marketing and processing in the form of sweets, yogurts, juices, liquors, and other products that use the striking characteristics of the fruit, such as its aroma, color, and flavor. Furthermore, strawberry is an important source of vitamin C (58.8 mg in $100 \mathrm{~g}$ ), vitamin A (12 IU in $100 \mathrm{~g}$ ), potassium (170 $\mathrm{mg}$ in $100 \mathrm{~g}$ ), folates, and calcium ( $2 \%$ of the recommended daily dose), also presenting other beneficial compounds, such as the high content of ellagic acid, a compound with high biological potential representing approximately $50 \%$ of the phenol content (HAKKINEN et al. 1999, CASALI 2004, QUINATO 2007, DUARTE FILHO et al. 2007, ROCHA et al. 2008).

In Brazil, strawberry cultivation is spread in temperate and subtropical climates, where the fruit is produced for fresh consumption and industrialization (SANTOS \& MEDEIROS 2003). The primary factors for commercially exploiting this crop are the high profitability when compared to other species such as corn and soybean, and the comprehensive knowledge and acceptance by the consumer due to the diversity of commercialization and fruit processing options (REICHERT \& MADAIL 2003, SANHUEZA et al. 2005, THIMOTEO et al. 2006).

Strawberry is a crop of high economic expression for Brazilian producers, representing most of the South American production, with 155 thousand tons and 4300 hectares produced in 2017 alone. Although Brazil is not present in FAO reports, some experts claim it occupies a position among the twenty largest world producers (ANTUNES 2018). The states of Minas Gerais, Paraná, and Rio Grande do Sul represent approximately $75 \%$ of the cultivated area and national strawberry production (FAGHERAZZI et al. 2017b).

The Vale do Rio Caí region in the state of Rio Grande do Sul is the main producer of table strawberries, followed by Caxias do Sul and Farroupilha. Pelotas and neighboring municipalities stand out in the production of strawberries for the industry, totalizing an annual production of approximately 11 thousand tons (ANTUNES \& REISSER JÚNIOR 2007, ANTONIOLLI et al. 2007). However, many table strawberry producers are moving to higher altitudes, which present a favorable climate and soil for cultivation. In this sense, the municipality of Vacaria, located in the Campos de Cima da Serra region, stands out with low temperatures favorable to the vegetative period of winter fruits, according to WREGE et al. (2007).

Oso Grande, Camarosa, and Strawberry Festival (short day) and Albion, San Andreas, Monterey, and Portola (neutral day), all developed in the United States, stand out among the main strawberry cultivars used in southern Brazil. When new strawberry cultivars are selected in breeding programs under local edaphoclimatic conditions and are subsequently disseminated to producing poles with different conditions, many do not express the same characteristics they presented where they were developed. In these cases, the cultivar will hardly produce high-quality fruit (CONTI et al. 2002, OLIVEIRA \& BONOW 2012).

One possible solution to compensate for the lack of fully adapted cultivars is the introduction of new cultivars. Some cultivars were introduced with few studies on their performance under Brazilian conditions in previous years, causing losses to farmers (PADUA et al. 2015). In this sense, new materials must be adequately assessed for adaptability in the region to which they will be introduced to ensure they meet the requirements of local producers and consumers (ASSIS 2004). Therefore, the choice of cultivars is one of the factors that largely determine the success of strawberry crops and must be linked to the climate characteristics of each location (DUARTE FILHO et al. 2007). For RUAN et al. (2013), the choice of cultivar is a crucial issue for the success of strawberry crops in different cultivation systems. To FAGHERAZZI (2013), success in strawberry cultivation is linked to several factors, such as the level of technical knowledge of the producers, the management, the edaphoclimatic conditions, and, especially, the choice of cultivars adapted to local conditions, to, therefore, satisfy producers and consumers.

Given the above, this study aimed to evaluate the productive and qualitative variables and the production seasonality of strawberry genotypes grown under the Campos de Cima da Serra Region (RS) conditions. 


\section{MATERIAL AND METHODS}

The research was developed from May 2014 to March 2015 in an experimental area in the municipality of Vacaria, RS, Brazil, in the Campos de Cima da Serra region, at latitude 28.30' South and longitude $50^{\circ} 56^{\prime}$ West, at an altitude of 922 meters. The climate of the region is temperate (Cfb1) according to the Köppen classification (MORENO 1961). The strawberries were cultivated in a fixed greenhouse with a side opening and a transparent polyethylene film cover $150 \mu \mathrm{m}$ thick.

The cultivars used were Strawberry Festival, Oso Grande, Jonica, and Pircinque, selections FRF PA3, FRF CE 51, FRF CE 56, FRF PIR 29, and FRF PIR 54 (short day), and selections FRF 85.04, FRF 149.18, and FRF 102.21 (neutral day), constituting the different treatments. A national nursery produced the "fresh" bare-root seedlings, and the transplant took place on May 13, 2014, in a semi-hydroponic production system in a greenhouse covered with UV diffuser plastic. The slab substrate was composed of $40 \%$ carbonized rice peel, $40 \%$ pine bark, and $20 \%$ vegetable cellulose. The slab had dimensions of $15 \mathrm{~cm}$ wide and $20 \mathrm{~cm}$ deep.

The planting density was 50 thousand plants per hectare, with a spacing of $0.15 \mathrm{~m}$ between plants. The basic fertilization was conducted according to the substrate analysis, using the recommendations described by PASSOS \& TRANI (2013). Drip irrigation was performed using one drip tape per cultivation line, with drippers spaced $10 \mathrm{~cm}$ apart. The nutrients were supplied via fertigation using the following products: potassium sulfate $\left(\mathrm{K}_{2} \mathrm{SO}_{4}\right)$, magnesium sulfate $\left(\mathrm{MgSO}_{4}\right)$, monoammonium phosphate (MAP), calcium nitrate $\left[\mathrm{Ca}\left(\mathrm{NO}_{3}\right)_{2}\right.$ ], potassium nitrate $\left(\mathrm{KNO}_{3}\right), \mathrm{P} 51$ (liquid fertilizer containing $51 \%$ phosphorus), and a micronutrientbased mixture. The electrical conductivity was maintained between $1 \mathrm{mS} . \mathrm{cm}^{-1}$ and $1.2 \mathrm{mS} . \mathrm{cm}^{-1}$, and its monitoring in the drained liquid was performed weekly. Pest and disease control was conducted using fungicides and insecticides recommended for the crop, when necessary.

Harvest began in October 2014, approximately five months after planting, and occurred weekly in the coolest hours of the day, when $80 \%$ of the epidermis was red. After harvesting, the fruits were evaluated at the Food Technology Center II (NUTA II) at the UDESC Center for Agroveterinary Sciences (CAV). Harvesting ended in March 2015, when the high temperatures of the summer period promoted the end of the production cycle for some genotypes and the sharp decrease in production for others.

The productive variables regarding the number of fruits $\left(\right.$ un plant $\left.^{-1}\right)$, production $\left(\mathrm{g} \mathrm{plant}^{-1}\right)$, fresh fruit mass $\left(g\right.$ fruit ${ }^{-1}$ ), classification of production in the percentage of commercial fruits, deformed fruits (fruits with deformation of the epidermis), small fruits (fruits with fresh mass $\leq 10 \mathrm{~g}^{\text {fruit }}{ }^{-1}$ ), and rotten fruits (presence of Botrytis cinerea and Colletotrichum fragariae) were evaluated. The distribution of monthly production seasonality during the harvest period was also estimated. The qualitative parameters analyzed were the contents of soluble solids expressed in ${ }^{\circ}$ Brix (determined using a digital bench refractometer), titratable acidity obtained by titration with a standardized $0.1 \mathrm{~N}$ sodium hydroxide solution, soluble solids to titratable acidity ratio, and pulp firmness obtained using a portable digital penetrometer with a No. 2 tip, with results expressed in $\mathrm{N}$.

The experimental design adopted was randomized blocks, with four blocks and one experimental unit of ten useful plants. The data collected were submitted to an analysis of variance and, when significant, their means were compared by the Scott-Knott test at $5 \%$ error probability. Subsequently, the multivariate analysis was performed for the principal component analysis (PCA) and correlation.

\section{RESULTS AND DISCUSSION}

A significant effect was found for all variables evaluated when comparing the studied genotypes. For the number of fruits per plant, cultivar Strawberry Festival and selections FRF CE 56 and FRF 102.21 showed the highest values, with 85,76 , and 87 fruits per plant, respectively. In contrast, these genotypes showed a general average of $78 \%$ or lower regarding the production considered fit for in natura fruits (\%), unlike cultivar Jonica and selection FRF 85.4, which presented the highest commercial production (approximately 90\%). FAGHERAZZI (2013) reported that, for other cultivars, a lower number of fruits produced per plant is consistent with a higher fresh weight and, consequently, a larger caliber.

Cultivars Strawberry Festival and selection FRF 102.21 showed the highest average production per plant: 1119.6 and 1138.5, respectively. A study conducted in Pelotas, RS, showed production values of 799.21 g.plant $^{-1}$ for cultivar Strawberry Festival, representing the most productive cultivar (CARVALHO et al., 2013). This result indicated that the production of S. Festival was superior compared to the other cultivars and selections. The productive difference found is approximately $22 \mathrm{~g}$ plant- $1,20 \%$ lower than in the study conducted by CARVALHO et al. (2013). These variations can be of biotic origins, such as a pathogen attack, or abiotic, such as climatic conditions like the high level of relative air humidity and the low light intensity, disfavoring plant development (VIDA et al. 2004). The climatic data regarding the average temperature $\left({ }^{\circ} \mathrm{C}\right)$ 
and rainfall $(\mathrm{mm})$ were monitored through the meteorological station of the National Institute of Meteorology (Table 1).

Table 1. Average values of the environmental variables measured in the 2014/2015 production cycle.

\begin{tabular}{lcccc}
\hline & $\begin{array}{c}\text { Mean Temperature } \\
\left(\text { Tmed; }^{\circ} \mathrm{C}\right)\end{array}$ & $\begin{array}{c}\text { Maximum } \\
\text { Temperature } \\
\left(\text { Tmax; }^{\circ} \mathrm{C}\right)\end{array}$ & $\begin{array}{c}\text { Minimum } \\
\text { Temperature } \\
\left(\text { Tmin; }^{\circ} \mathrm{C}\right)\end{array}$ & Rainfall $(\mathrm{mm})$ \\
\hline May & & $2014 / 2015$ & 8 & 76 \\
June & 13.5 & 19 & 6 & 92 \\
July & 11.5 & 17 & 6 & 159 \\
August & 11.5 & 17 & 7 & 131 \\
September & 12.5 & 18 & 9 & 176 \\
October & 14 & 19 & 11 & 145 \\
November & 16.5 & 22 & 12 & 107 \\
December & 18 & 24 & 14 & 138 \\
January & 19.5 & 25 & 15 & 121 \\
February & 20.5 & 26 & 15 & 127 \\
March & 20.5 & 24 & 14 & 114 \\
April & 19 & 21 & 10 & 75 \\
\hline Average & 15.5 & 21.50 & 10.58 & 121.75 \\
\hline
\end{tabular}

The same was observed for commercial productivity in cultivar Strawberry Festival and selection FRF

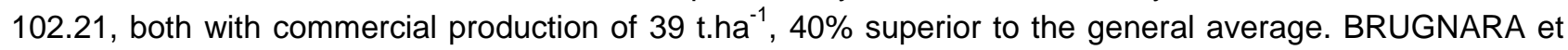
al. (2017) obtained similar average productivity values, ranging from 30 to 60, for Strawberry Festival, with a plant population of 5.53 plants per squared meter, in a study conducted in the west of Santa Catarina for the 2017/2018 harvest.

The neutral day selections FRF 85.4, FRF 149.18, and FRF 102.21 showed good harvest distributions (Table 2) since their average production in October, November, and December was $25 \%$. This characteristic must be explored because cultural techniques are a viable solution for the excess of fruit produced in a short time when there is little qualified labor to harvest, thus facilitating the flow of production with labor optimization (REIS et al. 2011).

Table 2. Production seasonality (\%) of the cultivars and selections evaluated in Vacaria, RS, Brazil, 2015.

\begin{tabular}{lcccccc}
\hline & \multicolumn{5}{c}{ Production Seasonality } \\
\cline { 2 - 7 } Genotype & \% OCT & $\%$ NOV & $\%$ DEC & $\%$ JAN & $\%$ FEB & $\%$ MAR \\
\cline { 2 - 7 } & & & & & & \\
\hline Jonica (SD) & $36 \mathrm{~b}$ & $21 \mathrm{~d}$ & $30 \mathrm{~d}$ & $09 \mathrm{e}$ & $01 \mathrm{e}$ & $02^{\mathrm{ns}}$ \\
Oso Grande (SD) & $39 \mathrm{a}$ & $19 \mathrm{e}$ & $29 \mathrm{e}$ & $10 \mathrm{e}$ & $01 \mathrm{e}$ & 02 \\
Pircinque (SD) & $30 \mathrm{~b}$ & $18 \mathrm{f}$ & $33 \mathrm{c}$ & $11 \mathrm{~d}$ & $06 \mathrm{~b}$ & 02 \\
Strawberry Festival (SD) & $27 \mathrm{~b}$ & $19 \mathrm{e}$ & $35 \mathrm{~b}$ & $11 \mathrm{~d}$ & $05 \mathrm{c}$ & 02 \\
FRF PA3 (SD) & $39 \mathrm{a}$ & $16 \mathrm{f}$ & $36 \mathrm{~b}$ & $06 \mathrm{f}$ & $01 \mathrm{e}$ & 02 \\
FRF CE 51 (SD) & $35 \mathrm{a}$ & $21 \mathrm{~d}$ & $34 \mathrm{~b}$ & $06 \mathrm{f}$ & $01 \mathrm{e}$ & 02 \\
FRF CE 56 (SD) & $19 \mathrm{c}$ & $22 \mathrm{~d}$ & $40 \mathrm{a}$ & $13 \mathrm{c}$ & $04 \mathrm{c}$ & 03 \\
FRF PIR 29 (SD) & $39 \mathrm{a}$ & $20 \mathrm{e}$ & $35 \mathrm{~b}$ & $03 \mathrm{~g}$ & $02 \mathrm{e}$ & 01 \\
FRF PIR 54 (SD) & $35 \mathrm{a}$ & $28 \mathrm{a}$ & $23 \mathrm{~g}$ & $09 \mathrm{e}$ & $02 \mathrm{~d}$ & 02 \\
FRF 85.4 (ND) & $29 \mathrm{~b}$ & $24 \mathrm{c}$ & $27 \mathrm{f}$ & $11 \mathrm{~d}$ & $07 \mathrm{a}$ & 03 \\
FRF 149.18 (ND) & $18 \mathrm{c}$ & $22 \mathrm{~d}$ & $29 \mathrm{e}$ & $19 \mathrm{a}$ & $08 \mathrm{a}$ & 04 \\
FRF 102.21 (ND) & $27 \mathrm{~b}$ & $26 \mathrm{~b}$ & $20 \mathrm{~h}$ & $18 \mathrm{~b}$ & $05 \mathrm{c}$ & 03 \\
\hline Mean & 31 & 21 & 31 & 11 & 04 & 02 \\
\hline CV (\%) & 8.4 & 3.9 & 2.4 & 5.4 & 13.9 & 28.5 \\
\hline
\end{tabular}

${ }^{*}$ Means followed by the same letter do not differ significantly by the Scott-Knott test at $5 \%$ of error probability.

$\mathrm{ND}=$ Neutral Day; SD = Short Day.

Rev. Ciênc. Agrovet., Lages, SC, Brasil (ISSN 2238-1171) 
For the percentage of production classified as commercial, cultivar Jonica and selections FRF 85.4, FRF PA3, FRF PIR 29, and FRF PIR 54 stood out, with an average of $85 \%$. This parameter is decisive for real production because of losses due to fungal diseases that may reach $100 \%$, according to COSTA et al. (2011).

When considering the fresh weight values, two groups were formed, one containing three of the commercial cultivars, namely Jonica, Oso Grande, and Pircinque, and selections FRF PIR 29, FRF PIR 54, and FRF 85.4, with an average fresh weight of $19.6 \mathrm{~g} \mathrm{fruit}^{-1}$, and the other formed by cultivar Strawberry Festival and selections FRF PA3, FRF CE 51, FRF CE 56, FRF 149.18, and FRF 102.21, with an average fresh mass of $14.8 \mathrm{~g}_{\text {fruit }^{-1}}$ (Table 3).

Table 3. Assessment of the productive characteristics of the evaluated genotypes separated according to their classifications in total (fruits per plant, production in grams per plant, and productivity tons per hectare) and commercial production (fresh mass in grams per fruit, commercial percentage, and productivity in tons per hectare). Vacaria, RS, Brazil, 2015.

\begin{tabular}{|c|c|c|c|c|c|c|}
\hline \multirow[b]{2}{*}{ Genotype } & \multicolumn{3}{|c|}{ Total production } & \multicolumn{3}{|c|}{ Production classified as commercial } \\
\hline & $\begin{array}{c}\text { Fruits } \\
\text { (un plant }^{-1} \text { ) }\end{array}$ & $\begin{array}{l}\text { Production } \\
{\left(\text { g plant }^{-1}\right)}\end{array}$ & $\begin{array}{l}\text { Productivity } \\
\left(\mathrm{t} \mathrm{ha}^{-1}\right)\end{array}$ & $\begin{array}{l}\text { Fresh Mass } \\
\left(\mathrm{g}_{\text {fruit }}^{-1}\right)\end{array}$ & $(\%)$ & $\begin{array}{l}\text { Productivity } \\
\left(\mathrm{t} \mathrm{ha}^{-1}\right)\end{array}$ \\
\hline Jonica (SD) & $49.1 \mathrm{c}$ & 727.7 b & $36.44 \mathrm{~b}$ & $21.9 \mathrm{a}$ & $85 a$ & $30.9 \mathrm{~b}$ \\
\hline Oso Grande (SD) & $58.2 \mathrm{~b}$ & $834.1 \mathrm{~b}$ & $41.7 \mathrm{~b}$ & $18.19 \mathrm{a}$ & $77 \mathrm{c}$ & $32.0 \mathrm{~b}$ \\
\hline Pircinque (SD) & $63.3 \mathrm{~b}$ & 878.3 b & $43.9 \mathrm{~b}$ & $21.1 \mathrm{a}$ & $72 d$ & $32.0 \mathrm{~b}$ \\
\hline Strawberry Festival (SD) & $85.1 \mathrm{a}$ & $1019.6 \mathrm{a}$ & $51.0 \mathrm{a}$ & $15.5 \mathrm{~b}$ & $78 \mathrm{c}$ & $39.7 \mathrm{a}$ \\
\hline FRF PA3 (SD) & $56.7 \mathrm{~b}$ & $567.9 \mathrm{c}$ & $28.4 \mathrm{c}$ & $12.3 \mathrm{~b}$ & $82 \mathrm{~b}$ & $23.3 c$ \\
\hline FRF CE 51 (SD) & $66.4 \mathrm{~b}$ & 784.4 b & $39.2 \mathrm{~b}$ & $15.3 \mathrm{~b}$ & $78 \mathrm{c}$ & $30.6 \mathrm{~b}$ \\
\hline FRF CE 56 (SD) & 75.9 a & 779.2 b & $39.0 \mathrm{~b}$ & $13.5 \mathrm{~b}$ & $74 \mathrm{~d}$ & $28.7 \mathrm{~b}$ \\
\hline FRF PIR 29 (SD) & $36.1 \mathrm{~d}$ & $506.8 \mathrm{c}$ & $25.3 \mathrm{c}$ & $18.0 \mathrm{a}$ & $80 \mathrm{~b}$ & $20.2 \mathrm{c}$ \\
\hline FRF PIR 54 (SD) & $47.2 \mathrm{c}$ & $708.9 \mathrm{~b}$ & $35.4 \mathrm{~b}$ & $18.0 \mathrm{a}$ & $81 \mathrm{~b}$ & $28.7 \mathrm{~b}$ \\
\hline FRF 85.4 (ND) & $28.4 \mathrm{~d}$ & $475.8 c$ & $23.8 \mathrm{c}$ & $20.3 a$ & $90 \mathrm{a}$ & $21.4 \mathrm{c}$ \\
\hline FRF 149.18 (ND) & $61.7 \mathrm{~b}$ & $821.4 \mathrm{~b}$ & $41.1 \mathrm{~b}$ & $16.1 \mathrm{~b}$ & $76 \mathrm{c}$ & $31.1 \mathrm{~b}$ \\
\hline FRF 102.21 (ND) & $87.1 \mathrm{a}$ & $1138.5 \mathrm{a}$ & $57.0 \mathrm{a}$ & $16.3 \mathrm{~b}$ & $69 \mathrm{~d}$ & $39.3 \mathrm{a}$ \\
\hline Mean & 59.6 & 770.2 & 38.5 & 17.2 & 78 & 29.8 \\
\hline CV (\%) & 12.7 & 11.9 & 11.9 & 13.1 & 3.8 & 12.3 \\
\hline
\end{tabular}

${ }^{*}$ Means followed by the same letter do not differ significantly by the Scott-Knott test at $5 \%$ of error probability. $\mathrm{ND}=$ Neutral Day; $\mathrm{SD}=$ Short Day.

The separate acidity values indicate that the FRF 102.21 selection has high acidity, $23 \%$ higher than the average, and commercial cultivars below average. Consequently, the SS to TA ratio of the FRF 102.21 selection was $26 \%$ below the average. For commercial cultivars, the average value is $15 \%$ superior to the average. Strawberry fruits with acceptable flavor must have a minimum of $7 \%$ soluble solids and a maximum of $0.8 \%$ titratable acidity (KADER 1991 ).

High levels of soluble solids are desirable in qualitative assessments, both for fresh consumption and for processing. Average levels are around $8 \%$ in ripe fruits (FARNEZI et al. 2020). Cultivar Pircinque stood out with an average value of $7.9^{\circ}$ Brix for the soluble solids content, which is positive since palatability is directly linked to the sugar content concerning acids, given by the antagonistic relationship cited by BRACKMANN et al. (2011).

Most cultivars reached an average of $3.2 \mathrm{~N}$ for pulp firmness, apart from cultivar Oso Grande and selections FRF 149.18, FRF CE 51, and FRF CE 56, which were below average (3.2 N) (Table 4). The FRF 85.4 genotype stood out with an average of $4.7 \mathrm{~N}$, presenting the highest values of pulp firmness, $33 \%$ superior to the other genotypes. Pulp firmness is a determining factor for the success of a cultivar since it allows a longer postharvest period and long-distance transport. This work showed a significant correlation between pulp firmness and commercial percentage (0.62), finding that a lower firmness is consistent with the fruit disposal rate, thus directly influencing the results of the commercial percentage described by FAGHERAZZI (2017a). 
Table 4. Assessment of the qualitative aspects of the fruits regarding the mean values for soluble solids (SS), total acidity (TA), SS to TA ratio, pulp firmness, and luminosity (L), chroma (C), and hue angle ( $\left.\mathrm{h}^{\circ}\right)$ of the epidermis color of the fruits of the evaluated genotypes. Vacaria, RS, Brazil, 2015.

\begin{tabular}{|c|c|c|c|c|c|c|c|}
\hline \multirow{2}{*}{ Genotype } & \multirow{2}{*}{$\begin{array}{c}\text { SS } \\
\text { (oBrix) }\end{array}$} & \multirow{2}{*}{$\begin{array}{c}\text { TA } \\
\text { (\% citric } \\
\text { acid) }\end{array}$} & \multirow{2}{*}{$\begin{array}{l}\text { Ratio } \\
\text { SS/TA }\end{array}$} & \multirow{2}{*}{$\begin{array}{l}\text { Firmness } \\
(\mathrm{N})\end{array}$} & \multicolumn{3}{|c|}{ Color } \\
\hline & & & & & $\mathrm{L}$ & C & $h^{o}$ \\
\hline Jonica (SD) & $6.2 \mathrm{~d}$ & $0.62 \mathrm{c}$ & $10.00 \mathrm{~d}$ & $3.4 \mathrm{~b}$ & $20.55 \mathrm{a}$ & $24.27 \mathrm{c}$ & $17.56 \mathrm{c}$ \\
\hline Oso Grande (SD) & $5.8 \mathrm{e}$ & $0.47 \mathrm{e}$ & $12.27 \mathrm{~b}$ & $2.4 \mathrm{c}$ & $17.96 \mathrm{~b}$ & $24.11 \mathrm{C}$ & $17.28 \mathrm{c}$ \\
\hline Pircinque (SD) & $7.9 \mathrm{a}$ & $0.57 \mathrm{~d}$ & $13.86 \mathrm{a}$ & $3.4 \mathrm{~b}$ & $19.24 \mathrm{~b}$ & $24.54 \mathrm{c}$ & $16.39 \mathrm{~d}$ \\
\hline Strawberry Festival (SD) & $6.4 \mathrm{~d}$ & $0.57 d$ & $11.15 \mathrm{C}$ & $3.3 \mathrm{~b}$ & $18.69 \mathrm{~b}$ & $23.31 d$ & $17.52 \mathrm{c}$ \\
\hline FRF PA3 (SD) & $7.4 \mathrm{~b}$ & $0.61 \mathrm{c}$ & $12.10 \mathrm{~b}$ & $3.2 \mathrm{~b}$ & $20.21 \mathrm{a}$ & $26.37 \mathrm{~b}$ & $17.50 \mathrm{c}$ \\
\hline FRF CE 51 (SD) & $6.6 \mathrm{c}$ & $0.63 \mathrm{c}$ & $10.40 \mathrm{~d}$ & $2.9 \mathrm{~b}$ & $21.60 \mathrm{a}$ & $27.98 \mathrm{a}$ & $17.81 \mathrm{c}$ \\
\hline FRF CE 56 (SD) & $6.3 \mathrm{~d}$ & $0.68 \mathrm{~b}$ & $9.33 \mathrm{~d}$ & $3.0 \mathrm{~b}$ & $20.59 \mathrm{a}$ & $26.89 \mathrm{~b}$ & $18.49 \mathrm{~b}$ \\
\hline FRF PIR 29 (SD) & $6.1 \mathrm{e}$ & $0.63 \mathrm{c}$ & $9.62 \mathrm{~d}$ & $3.6 \mathrm{~b}$ & $21.72 \mathrm{a}$ & $25.10 \mathrm{C}$ & $19.38 \mathrm{a}$ \\
\hline FRF PIR 54 (SD) & $6.2 \mathrm{~d}$ & $0.63 \mathrm{c}$ & $9.83 \mathrm{~d}$ & $3.2 \mathrm{~b}$ & $19.17 \mathrm{~b}$ & $25.80 \mathrm{~b}$ & $17.53 \mathrm{c}$ \\
\hline FRF 85.4 (ND) & $6.6 \mathrm{c}$ & $0.67 \mathrm{~b}$ & $9.81 \mathrm{~d}$ & $4.7 \mathrm{a}$ & $19.21 \mathrm{~b}$ & $25.93 \mathrm{~b}$ & $17.51 \mathrm{c}$ \\
\hline FRF 149.18 (ND) & $5.8 \mathrm{e}$ & $0.58 d$ & $9.88 \mathrm{~d}$ & $2.6 \mathrm{c}$ & $19.47 \mathrm{~b}$ & $24.30 \mathrm{c}$ & $18.48 \mathrm{~b}$ \\
\hline FRF 102.21 (ND) & $5.9 \mathrm{e}$ & $0.76 \mathrm{a}$ & $7.77 \mathrm{e}$ & $3.2 \mathrm{~b}$ & $16.40 \mathrm{c}$ & $22.12 \mathrm{~d}$ & $15.88 d$ \\
\hline Mean & 6.4 & 0.62 & 10.5 & 3.2 & 19.57 & 25.06 & 17.61 \\
\hline CV (\%) & 2.6 & 3.7 & 5.2 & 7.4 & 4.8 & 3.3 & 2.3 \\
\hline
\end{tabular}

${ }^{*}$ Means followed by the same letter do not differ significantly by the Scott-Knott test at $5 \%$ of error probability. ND = Neutral Day; SD = Short Day.

When considering the epidermis color, the luminosity parameter was divided into three groups (Table 4), where cultivar Jonica and selections FRF PA3, FRF CE 51, FRF CE 56, and FRF PIR 29 were above the average. None of the commercial cultivars presented epidermis saturation above the average (25.06) regarding the chroma variable, and the same behavior was observed for the hue angle. Only selections FRF CE 51 and FRF PIR 29 differed from the others regarding the degree of saturation (chroma) and hue angle, respectively. Luminosity, chroma, and hue had a direct, negative, and significant correlation $(<5 \%)$ with production and productivity. Therefore, higher production is consistent with a greater dilution of the epidermis pigments, so cultivars with high production commonly produce fruits with depigmented or little pigmented interiors (CASTRO 2004, DUARTE FILHO et al. 2007).

Among the short-day commercial cultivars (Jonica, Oso Grande, Pircinque, and Strawberry Festival), only cultivar Oso Grande had considerable production in October, representing 39\% of its total production. This is consistent with the data obtained by GONÇALVES et al. (2016), who demonstrated that this cultivar has a high precocity under the conditions of the municipality of Pelotas, RS, compared with other commercial cultivars. The production of the other commercial cultivars (Pircinque, Jonica, and Strawberry Festival) was diluted over the evaluated months, presenting a significant drop from February, with average production decreasing around $50 \%$ per month.

Four of the five short-day selections (FRF PA3, FRF CE 51, FRF PIR 29, FRF PIR 54) had an average production of $37 \%$ in October. Selection FRF CE 56 produced $40 \%$ of its total production in December. Selections FRF PIR $54(23 \%)$ and FRF $102.21(20 \%)$ were the only selections that presented production peaks in December compared to the average of the other selections (33\%).

Figures 1 and 2 show the divergence between neutral-day and short-day cultivars. Most of the shortday cultivars and selections presented low production in January, given that they suffer a strong influence of the photoperiod. When referring to adaptation, strawberries are directly affected by two environmental factors: temperature, neutral-day (ND) and short-day (SD) cultivars, and photoperiod for SD cultivars, since the temperature may affect floral induction differentiation and fruit development, consequently influencing the productivity and quality of the fruits (HONJO et al. 2016). 

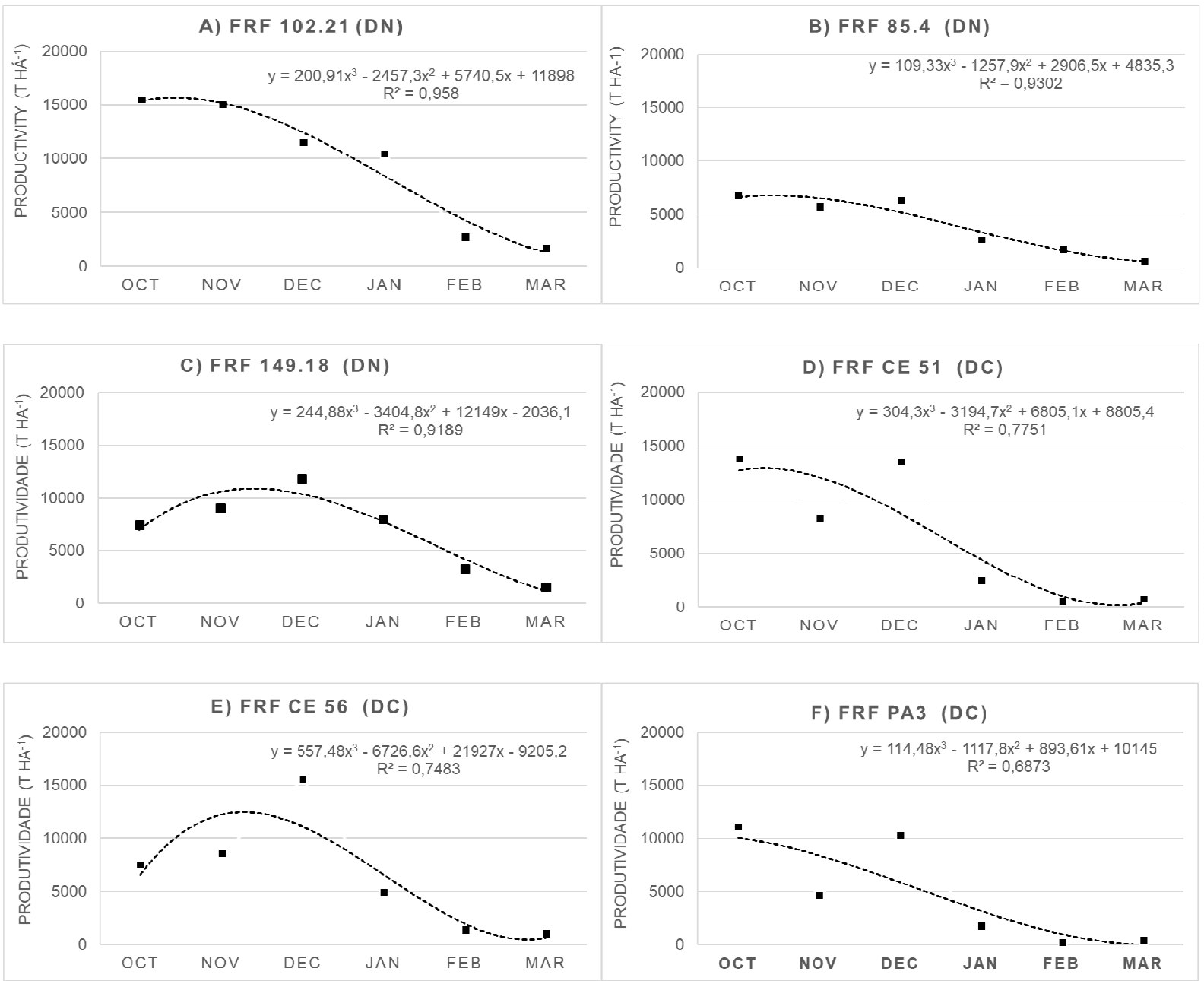

ND = Neutral Day; SD = Short Day. Source: The author, 2019.

Figure 1. Seasonal variation of the commercial production $\left(g \operatorname{plant}^{-1}\right)$ for genotypes (a) Jonica, (b) Oso Grande, (c) Pircinque, (d) Strawberry Festival, (e) FRF PA3, and (f) FRF CE 51 during the 2015/2016 cycle. Vacaria, RS, Brazil, 2020.
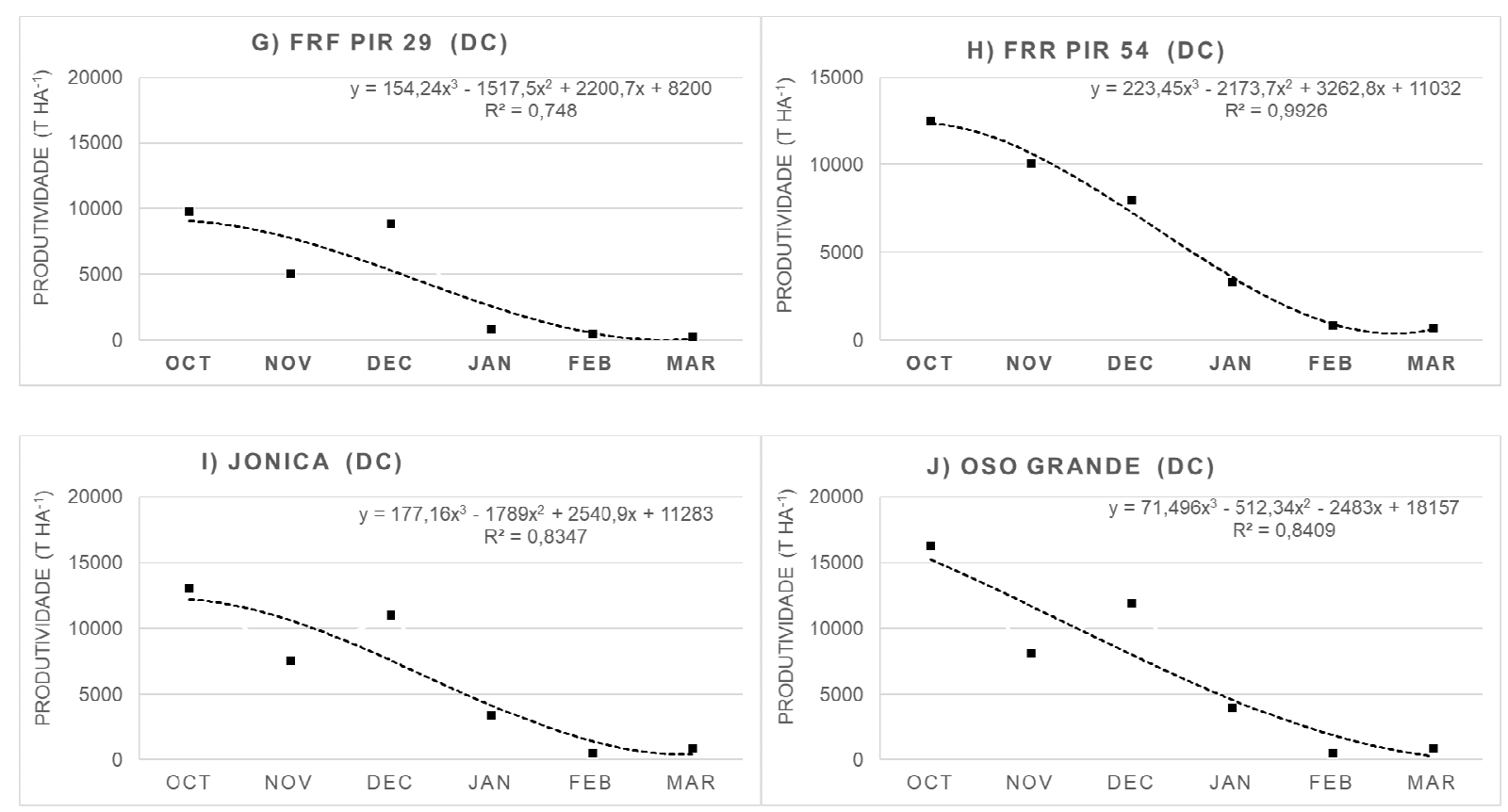
Continuation Figure 2.
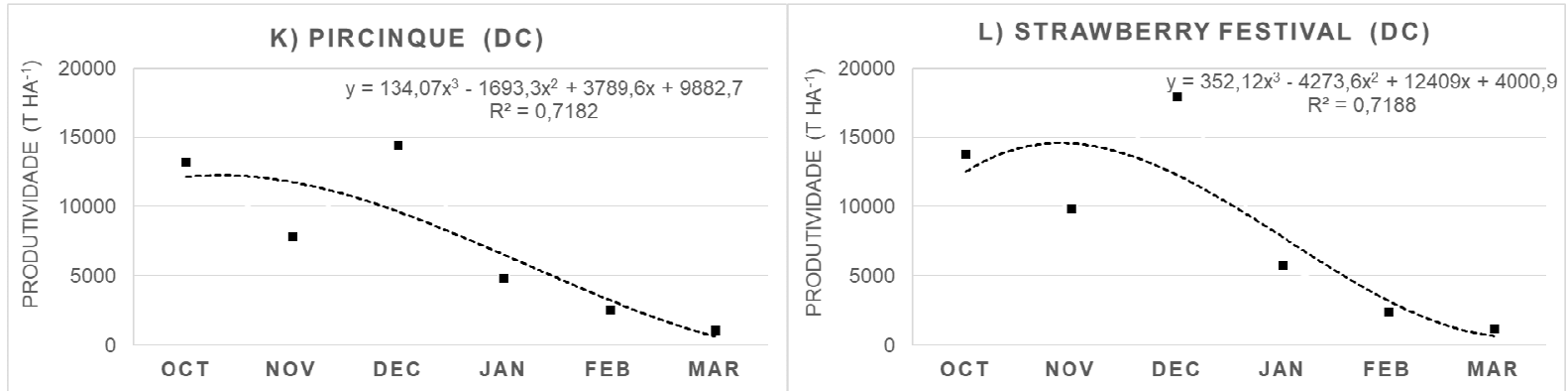

Caption: ND = Neutral Day; SD = Short Day. Source: The author, 2019.

Figure 2. Seasonal variation of the commercial production $\left(g\right.$ plant $^{-1}$ ) for genotypes (g) FRF CE 56, (h) FRF PIR 29, (i) FRF PIR 54, (j) FRF 85.4, (k) FRF 149.18, and (I) FRF 102.21 during the 2015/2016 cycle. Vacaria, RS, Brazil, 2020.

The principal component analysis (PCA) (Figure 3) showed four distinct groups. Group I, included in principal component 1 (CP2), consisted of cultivars Pircinque and Oso Grande, genotypes correlated with -Brix, SS to TA ratio, and fresh weight. Group II, arranged on the CP1 axis, consisted of cultivar Jonica and selections FRF PA3, FRF CE 51, FRF PIR 29, FRF PIR 54, and FRF 85.4, presenting a correlation for commercial production percentage, pulp firmness, luminosity, Chroma, and hue angle, with colors far from red. Group III was formed by selections FRF CE 56 and FRF 149.18, grouped with the acidity variable in the CP2 axis. Group IV, arranged in CP1, was composed by selection FRF 102.21 and cultivar Strawberry Festival, both arranged contrary to the chemical and physical fruit quality parameters (soluble solids, soluble solids to titratable acidity ratio, epidermis color) highly correlated with productive parameters (fruits per plant, production per plant, productivity, commercial productivity).

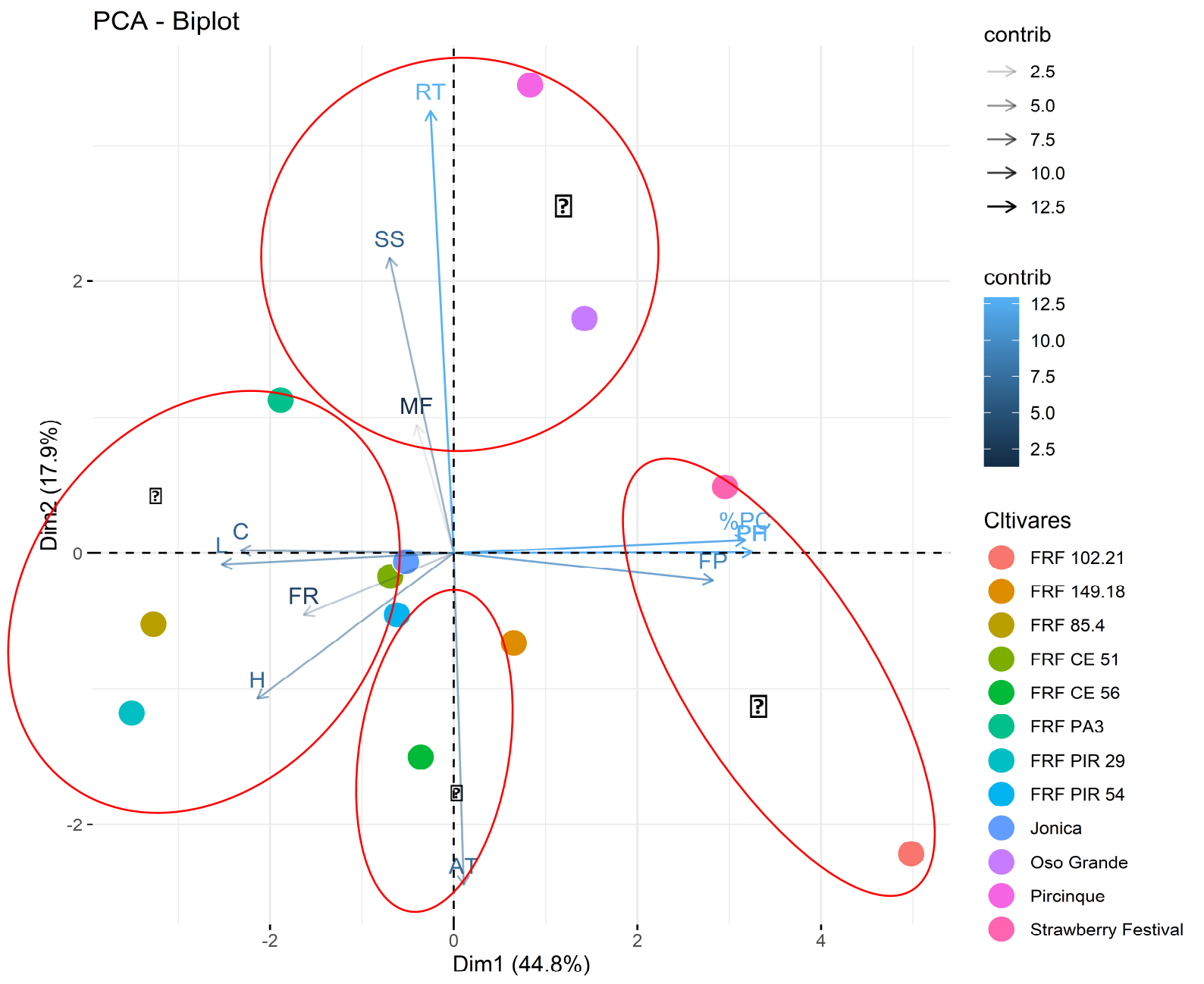

Figure 3. Principal component analysis for the variables, cultivars, and selections evaluated in Vacaria, RS, Brazil, 2015. 
Total soluble solids (Figure 4) have a significant (0.67) positive correlation with the SS to TA ratio because it is the numerator of said ratio. On the other hand, the correlation between TA and the SS to TA ratio is highly significant and negative $(-0.77)$, given that it is the ratio denominator. ZANIN et al. (2019) had previously reported similar values $(-0.71)$ for the same correlation in a study with sixteen strawberry genotypes conducted in the municipality of Lages, Santa Catarina.

The number of fruits per plant has a high correlation with dependent variables or even those derived from it, such as commercial production. The same is true for production per plant and productivity and percentage of commercial fruits, also reported by FAGHERAZZI (2017b) and ZANIN et al. (2019).

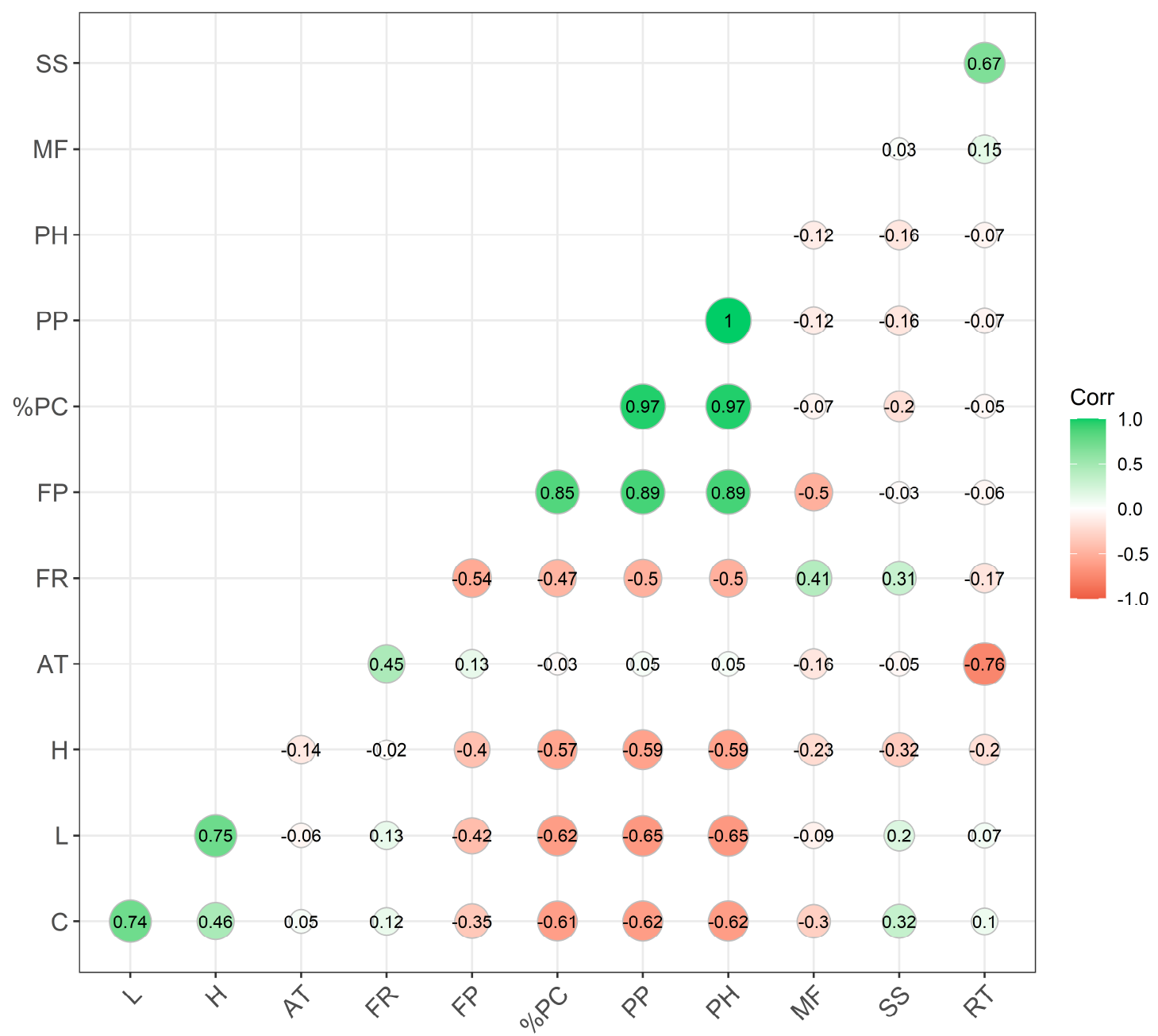

Correlation matrix, positive correlations are displayed in blue and negative correlations in red color. Color intensity and the size of the circle are proportional to the correlation coefficients.

Caption: $\mathrm{FP}=$ fruits per plant. $\mathrm{PP}=$ production per plant. $\mathrm{PH}=$ productivity per hectare. $\mathrm{FM}=$ fresh mass. $\% \mathrm{CP}=$ commercial percentage. $\mathrm{SS}=$ content of soluble solids. $\mathrm{FR}=$ firmness. $\mathrm{TA}=$ titratable acidity. RT $=$ soluble solids/titratable acidity ratio. $\mathrm{LM}=$ epidermis luminosity. $\mathrm{CR}=$ epidermis chroma. $\mathrm{H}=$ epidermis hue angle.

Figure 4. Pearson correlation matrix among the variables obtained in the adaptability study of the cultivars and selections evaluated in Vacaria, RS, Brazil, 2015.

\section{CONCLUSION}

The Strawberry Festival, Jonica, and Pircinque cultivars and the FRF 102.21 selection were best adapted to the climate conditions of Vacaria, RS, Brazil, concerning both qualitative and quantitative data. The Strawberry Festival cultivar and the FRF 102.21 selection presented the highest productivities per hectare.

\section{REFERENCES}

ANTONIOLLI LR et al. 2007. Boas práticas na cultura do morangueiro. Porto Alegre: SEBRAE/RS.

ANTUNES LEC. 2018. Brasil é o maior produtor de morango da América do Sul. Campo \& Negócio-Hortifruti 7: 92-94.

ANTUNES LEC \& RESENDE JUNIOR C. 2007. Fragole, i prodottori brasiliani mirano all'esportazione in Europa. Frutticoltura 69: 60-65. 
ASSIS M. 2004. Produção de matrizes e mudas de morangueiro no Brasil. In: Simpósio Nacional do Morango e Encontro de Pequenas Frutas e Frutas Nativas. Anais... Pelotas: Embrapa Clima Temperado. p. 45-50.

OLIVEIRA ACB \& BONOW S. 2012. Novos desafios para o melhoramento genético da cultura do morangueiro no Brasil. Informe Agropecuário 33: 21-26.

BRACKMANN A et al. 2011. Avaliação de genótipos de morangueiro quanto à qualidade e potencial de armazenamento. Revista Ceres 58: 542-547.

BRUGNARA EC et al. 2017. Morango. In: Avaliação de cultivares para o estado de Santa Catarina 2017-2018. Florianópolis: Epagri. p.56-57. (Boletim Técnico 176).

CARVALHO SF et al. 2013. Comportamento e qualidade de cultivares de morango (Fragaria $x$ ananassa Duch.) na região de Pelotas-RS. Revista Iberoamericana de Tecnología Postcosecha 14: 176-180.

CASALI ME. 2004. Atraso no resfriamento e modificação da atmosfera para morangos. Dissertação (Mestrado em Fitotecnia). Porto Alegre: UFRGS. 65p.

CASTRO RL. 2004. Melhoramento genético do morangueiro: avanços no Brasil. In: RASEIRA MCB et al. (Ed.) Simpósio Nacional do Morango e Encontro de Pequenas Frutas e Frutas Nativas do Mercosul. Pelotas: Embrapa Clima Temperado. 296p. (Documentos 124).

CONTI JH et al. 2002. Produção e qualidade de frutos de diferentes cultivares de morangueiro em ensaios conduzidos em Atibaia e Piracicaba. Horticultura Brasileira 20: 10-17.

COSTA H et al. 2011. Manejo integrado de doenças do morangueiro. Horticultura Brasileira 29: 5856-5877.

DUARTE FILHO J et al. 2007. Morango: conquistando novas fronteiras. Informe Agropecuário 28: $20-23$.

FAGHERAZZI AF. 2013. Avaliação de cultivares de morangueiro no Planalto Sul Catarinense. Dissertação (Mestrado em Produção Vegetal). Lages: UDESC. 107p.

FAGHERAZZI AF. 2017a. La cultivazione dei piccoli frutti in Sud America: non solo mirtilli. Embrapa Clima Temperado. Frutticoltura 7/8: 44-47.

FAGHERAZZI AF. 2017b. Adaptabilidade de novas cultivares e seleções de morangueiro para o Planalto Sul Catarinense. Tese (Doutorado em Produção Vegetal). Lages: UDESC. 144p.

FAOSTAT. 2019. Statistics Database. Most produced commodities, Brazil. Disponível em: http://www.fao.org/faostat/en/\#data/QC/visualize. Acesso em: 15 nov. 2020.

FARNEZI PKB et al. 2020. Production and physical and chemical characterization of strawberry under diferente sources of phosphate fertilization. Brazilian Journal of Development 6: 65051-65066.

GONÇALVES MA et al. 2016. Comportamento produtivo de cultivares de morangueiro estabelecido a partir de mudas com torrão. Revista Eletrônica Científica da UERGS 2: 277-283.

HAKKINEN S et al. 1999. Screening of selected flavonoids and phenolic acids in 19 berries. Food Research International 32: 345-353.

HONJO M et al. 2016. Simple sequence repeat markers linked to the everbearing flowering gene in long-day and day-neutral cultivars of the octoploid cultivated strawberry Fragaria $\times$ ananassa. Euphytica 209: 291303.

KADER A. 1991. Quality and its maintenance in relation to postharvest physiology of Strawberry. In: DALE A \& LUBY JJ. (Ed.). The Strawberry into the 21 st. Oregon: Timber Press. p.145-152.

MORENO JA. 1961. Clima do Rio Grande do Sul. Porto Alegre: Secretaria da Agricultura. 42p.

PASSOS FA \& TRANI PE. 2013. Calagem e adubação do morangueiro. Campinas: Instituto Agronômico de Campinas. $16 \mathrm{p}$.

QUINATO EE et al. 2007. Aspectos Nutricionais e Funcionais do Morango. Visão Acadêmica 8: 11-17.

REICHERT LJ \& MADAIL JCM. 2003. Aspectos Socioeconômicos morango. Embrapa Informação Tecnológica 40: 3538.

REIS KM et al. 2011. Sazonalidade de preço e quantidade comercializada de morango nos CEASAs-MG de 1995 a 2010. Horticultura Brasileira 29: 2404-2408.

ROCHA DA et al. 2008. Análise comparativa de nutrientes funcionais em morangos de diferentes cultivares da região de Lavras-MG. Revista Brasileira de Fruticultura 30: 1124-1128.

RUAN $J$ et al. 2013. Flowring and Fruiting of Day-neutral and Ever-bearing Strawberry Cultivars in Highelevation for Summer and Autumn Fruit Production in Korea. Horticulture, Environment, and Biotechnology 54: 109-120.

SANHUEZA RMV et al. 2005. Sistema de produção de morango para mesa na Região da Serra Gaúcha e Encosta Superior do Nordeste. Disponível em: http://sistemasdeproducao.cnptia.embrapa.br/FontesHTML/Morango/MesaSerra Gaucha/importancia.htm. Acesso em: 03 ago. 2019.

SANTOS AM \& MEDEIROS ARM. 2003. Morango: produção. Brasília: Embrapa Informação Tecnológica. 81p. (Frutas do Brasil 40).

THIMOTEO A. et al. 2006. Expectativa de retorno e risco da produção de morangos no município de Guarapuava - PR. In: 46ํㅡㄹ Congresso Brasileiro de Olericultura. Goiânia: Horticultura Brasileira 24. CD- Rom.

VIDA JB et al. 2004. Manejo de doenças de plantas em cultivo protegido. Fitopatologia Brasileira 29: 355-372.

WREGE MS et al. 2007. Zoneamento agroclimático para produção de mudas de morangueiro no Rio Grande do Sul. Pelotas: Embrapa Clima Temperado. 27p. (Documentos 187).

ZANIN DS et al. 2019. Agronomic performance of cultivars and advanced selections of strawberry in the South Plateau of Santa Catarina State. Revista Ceres 66: 159-167. 